\title{
El recurso metalingüístico y la performatividad en la samba. Una propuesta de análisis desde la semiótica cultural
}

\author{
O recurso metalinguístico e a performatividade no samba. \\ Uma proposta de análise a partir da semiótica cultural \\ The metalinguistic resource and samba's performativity. \\ A purpose of analysis from the semiotics of culture
}

AUTOR

\section{Sandra Fuentes de Azevedo*}

fuentesdeazevedo sandra9@gmail.com

* Máster en Estudios Literarios por la Universidad Complutense de Madrid (España).

\section{RESUMEN:}

Con el siguiente estudio se pretende poner en práctica un análisis discursivo de la samba desde una óptica multidisciplinar. Para ello nos servimos, entre otros, de los estudios de semiótica cultural y musical del doctor Juan Miguel González Martínez; del estudio de metalenguaje en la samba de André Nemi Conforte y de la propuesta performática en Austin. Dichos trabajos además de servir como soporte teórico nos ayudan a comprender el mecanismo por el que se rige la samba para construir lo que Lubomír Doležel denomina, mundos posibles, y que no es otra cosa que símbolos y signos que pasan a formar parte de una realidad y, por ende, de una memoria colectiva. De este modo, la samba - texto inteligente -, sus compositores y sus oyentes construyen una armazón semiótica capaz de reproducirse y retroalimentarse a lo largo de los años, dando como resultado una identidad sociocultural. Finalmente se deduce el poder de la música, sobre todo en el género que nos ocupa, el cual no solo funciona como canal de comunicación, sino que además goza de un papel importantísimo: el de crear conciencia histórica.

\section{RESUMO:}

No presente estudo, pretendemos realizar uma análise discursiva do samba a partir de uma ótica multidisciplinar. Para isso, partimos da semiótica cultural e musical do professor Juan Miguel González Martínez; nos estudos sobre metalinguagem no samba de André Nemi Conforte, e na proposta performática em Austin. Estes trabalhos, além de servirem como suporte teórico, nos ajudam a compreender o mecanismo pelo qual o samba se rege, para se configurar e formar aquilo que Lubomír Doležel chama de mundos possíveis, formados por símbolos e signos que passam a fazer parte da nossa realidade e, por conseguinte, da memória coletiva. Dessa forma, o samba (uma espécie de texto inteligente), seus compositores e ouvintes constroem uma cadeia semiótica capaz de se reproduzir e de se retroalimentar ao longo do tempo, tendo como resultado uma identidade social. Por fim, entendemos o poder da música não só como um canal de comunicação, mas também como criadora indiscutível de uma consciência histórica.

\section{ABSTRACT:}

The following study intends to put into practice a discursive analysis of Samba from a multidisciplinary perspective. For this we use, among others, the studies of cultural and musical semiotics by professor Juan Miguel González Martínez; of the study of metalanguage in samba by André Nemi Conforte and the performative proposal in Austin. These works, in addition to serving as theoretical support, help us understand the mechanism by which samba is guided to build what Lubomír Doležel calls possible worlds, 
which is nothing but symbols and signs that become part of a reality and, therefore, of a collective memory. In this way, Samba - an intelligent text -, its composers and listeners build a semiotic framework capable of reproducing and providing feedback over the years, resulting in a social identity. Finally, the power of music is deduced, especially in the genre in question, which works not only as a channel of communication, but also plays an important role: to create a historical awareness. 


\section{Introducción}

El propósito principal del presente artículo es ofrecer un método de análisis de canciones de samba desde un punto de vista lingüístico-literario. Para poder comprender cómo funciona el universo de la samba nos inclinamos por un estudio de corte diacrónico cuyas bases se asientan en un método semiótico. Asimismo, para poder abordar los aspectos sociológicos que atañen a la producción musical nos apoyaremos en la propuesta semiótica del investigador Juan Miguel González Martínez, profesor y especialista en semiótica musical de la Universidad de Murcia (España), quien en sus estudios sugiere un análisis del discurso musical y lingüístico ecuánime, es decir, concibiendo a ambos como, lo que acuña, un todo heterosemiótico. Seguidamente, usaremos la teoría performativa y la teoría de los mundos posibles para explicar el fenómeno que hay tras el salto de ciertas imágenes presentes en la samba al mundo real y que contribuyen a labrar un imaginario y una memoria colectivas. Dicha cualidad performativa confiere a la samba el don de la autorreferencialidad, aspecto que le permite llamar la atención sobre su propio proceso de elaboración. Esta situación será explicada por el doctor André Nemi Conforte quien descubre en la samba una tendencia metalingüística mediante la cual se posibilita precisamente dicha autorreferencialidad. Ante esto, Conforte establece tres tipos de sambas metalingüísticas: metassambas, sambas metapoéticos y sambas propriamente dichos. En definitiva, lo que se busca con esta propuesta analítica es demostrar, entre otras cosas, la versatilidad de disciplinas como la lingüística y la literatura, contribuyendo a la remodelación teórica de los diferentes estudios para crear análisis multidisciplinares y, por consiguiente, más fidedignos con las realidades humanas. Así, se nos anima a participar del gran mecanismo generador de la samba la cual mantiene constantemente una lucha con su propio quehacer artístico. A raíz de esa lucha interior, el compositor y la propia samba, explican sus orígenes construyendo mundos posibles y enciclopedias que ayudan a la conservación de los orígenes de la samba desde sus inicios hasta nuestros días.

\section{Hacia el camino de la conciliación artística: la heterosemiosis}

Entre los aspectos que debemos tener en cuenta a la hora de abordar el universo musical se encuentra el hecho de que, ante todo, se trata de un fenómeno artístico y por tanto está supeditado al contexto, cambiando y transformándose en función de él. Asimismo, la música, tal y como recoge el investigador, González Martínez, en Fundamentos de la semiótica de la música (2015), "se constituye como un sistema convencional de signos, lo que supone un proceso de interpretación y esto implica la existencia de comunicación" (p. 390). Precisamente esta naturaleza comunicativa será lo que le confiera a la música el estatus de signo y, por consiguiente, de lenguaje. Dicha premisa ya está presente en las teorías de Umberto Eco quien en su ensayo "La estructura ausente" postula: "Todos los procesos culturales son procesos de comunicación” (Eco, 1986 apud González Martínez, 2015, p. 386), aspecto que convierte a la música a la música en objeto de estudio de la semiótica, concretamente, de la semiótica cultural. Teniendo en cuenta esta concepción de la música, González Martínez explica que será "precisamente su valor sémico lo que le da carácter social al arte - entendiendo por supuesto música, como arte - y mediante su análisis semiológico podrá superarse el formalismo de los métodos inmanentistas" (2015, p. 386). Como consecuencia, lo que en principio podía parecer un análisis compartimentado se convierte en un estudio homogéneo de carácter multidisciplinar en donde el nivel instrumental y vocal coexisten en armonía.

En el apartado "Potencial comunicativo de la música" de su ensayo, González Martínez (2015) expone una distinción que, a riesgo de parecer una obviedad, resulta ser de gran interés para
PALABRAS CLAVE Samba; metalenguaje; mundos posibles; performatividad; semiótica.

PALAVRAS-CHAVE Samba;

metalinguagem; mundos possíveis; performatividade; semiótica.

KEYWORDS Samba; metalanguage; possible worlds; performativity; semiotics.

Recibido:

23/04/2019

Aceptado:

25/06/2019 
- EL RECURSO METALINGÜÍSTICO Y LA PERFORMATIVIDAD EN LA SAMBA.

UNA PROPUESTA DE ANÁLISIS DESDE LA SEMIÓTICA CULTURAL •

SANDRA FUENTES DE AZEVEDO

encarar nuestro análisis. Para éste "en el caso concreto de la música hay dos criterios que permiten hablar de comunicación: la elección y la intención de comunicación” (p. 390). Del primer supuesto extraemos los interrogantes "qué" y "porqué"; mientras que de la segunda cuestión se deduce el "para qué". Por consiguiente, del primero se extrae el sentido latente de esa estructura discursiva, y del segundo se deduce el alcance que tiene dicha estructura. Es decir, si escogemos el lenguaje musical pudiendo escoger otro, se deduce que tras esta elección hay una serie de factores causales que debemos tener en cuenta. Por eso, para el semiotista, no sería necesario "ser conscientes o capaces de reproducir el proceso de elección realizado por el autor para entender lo que se desprende de la elección de una opción determinada" (2015, p. 390) ya que, en la propia elección, reside la respuesta. Dicho esto, bajo el criterio de elección subyacen todas aquellas cuestiones relacionadas con los factores de consolidación de la samba y que ilustrarían el qué es la samba, cómo surge y por qué es tan importante para los brasileños. Para ello, resulta ineludible el fenómeno de mestizaje afro-indígena durante el período de colonización y el consecuente surgimiento de los primeros estilos musicales (lundú, maxixé, modinhas, choros, etc.); la higienización racial surgida tras la abolición de la esclavitud y la consiguiente movilización migratoria de esclavos y negros bantos ${ }^{1}$ a la capital. A consecuencia de esto, se originan una serie de disputas entre las clases bajas y altas, siendo las primeras las conformadas por los antiguos esclavos y sus descendientes, quienes establecen residencia en los morros y en núcleos como la Pequena África; y el segundo grupo estará conformado por una masa aburguesada con inclinaciones eurocentristas que reniega de la causa indígena y que considera las tradiciones como algo pagano y primitivo. El arrinconamiento al que fueron sometidas las clases bajas propició, en cambio, un fenómeno polifónico fruto de la diversidad étnica: "Todo esse empenho, em décadas de tentativa de exclusão da inventividade popular, mostra-se inócuo, pois justamente nesse mesmo período se dá o processo de fixação dos nossos principais gêneros musicais urbanos" (Fenerik apud Santos de Miranda, 2007, p. 89). De ahí que incluso muchos géneros gestados en los morros comenzasen a institucionalizarse, contribuyendo a la conciencia autoral entre los grupos más humildes. La tregua (que no reconciliación) entre ambas clases tendrá que esperar hasta la aparición de la radio, momento en que el ambas se sitúan en un mismo nivel de recepción. A esto se suma el proceso de palatalización por el que pasa la música brasileña para consolidarse puesto que "no caso do samba, ele também precisava se educar e transformar-se em sinônimo de cultura, semelhante ao processo observado no teatro de revista (sinônimo de mau gosto) em relação ao teatro (este, então, uma arte sofisticada e inteligente)" (Fenerik, 2005, p. 72). Dicha situación se promueve entre otras cosas por el Estado Novo y el régimen de Getúlio Vargas, quien aprovecha la fuerte personalidad impresa en algunas imágenes, hasta entonces consideradas marginales, y las convierte en símbolos de exaltación nacional. Por último, habría que tener en cuenta la constante atmósfera de tensión en donde lo político se extrapola al universo artístico, el cual acaba por convertirse en campo de batalla y terreno de exacerbación social. Como consecuencia, la samba se erige como símbolo representativo de la cultura brasileña y en lugar común donde expresar ideas tanto politizadas como no politizadas.

Dejando a un lado la cuestión histórico-social, para contestar a las preguntas de esta primera fase propuesta por González Martínez, es necesario prestar atención a los tres componentes fundamentales de los sistemas de comunicación, pues cada uno dispone de una función concreta. Así, nos encontraríamos con el Autor, vox populi bautizado por González Martínez como "manipulador no violento”, es decir, una suerte de Yo lírico que aprovecha su situación de privilegio para hacer llegar su mensaje; el Auditorio, quien reconoce en éste un modelo capaz de manejar con fluidez un lenguaje repleto de redes isotópicas:

El cantante necesita disponer de un bagaje de fórmulas para poder repetirlas en diferentes contextos y también debe tener muy a mano un conjunto de temas para insertarlos de forma semejante en cualquier relato, y así adaptarlo a los nuevos contextos con el mínimo de cambios (Parry y Lord, 1976; apud Hodge, 1999, p. 159).

Y en última instancia el Texto, cuyo código va a tener una forma determinada (nunca casual) en donde voz y palabra resultarán claves, y en donde pergeñan todas aquellas tensiones tan características del universo de la samba. Dichos factores son cruciales para la conformación del sistema de la samba pues contribuyen a crear una mayor conciencia estética del género. A esto se suma el auge de los medios de comunicación, destacando la labor de la radio, y la continua búsqueda de elementos generadores de identidad impulsados 
- EL RECURSO METALINGÜÍSTICO Y LA PERFORMATIVIDAD EN LA SAMBA.

UNA PROPUESTA DE ANÁLISIS DESDE LA SEMIÓTICA CULTURAL •

SANDRA FUENTES DE AZEVEDO

principalmente por las diversas situaciones de choque entre lo propio y lo ajeno. Por estas razones, y otras que aquí no se mencionan, sería un error no prestar atención a las letras, pues en ellas los compositores y los letristas, conocedores de primera mano del género y su tradición, exponen gran parte de la información necesaria para comprender de qué trata este universo. Gracias a estos generadores de sentido y a las múltiples limitaciones a las que se ha enfrentado la música brasileña durante su gestación, el compositor de samba emprende una labor didáctica por la cual se fijan determinadas directrices, facilitando con ello la comprensión de la samba como género canónico.

En relación con esto último, resulta muy interesante observar el fenómeno producido tras el surgimiento de la bossa nova, género que cambia en muchos aspectos la forma no sólo de concebir la música en Brasil, sino de producirla y absorberla en tanto que género. El caso de la bossa nova es cuanto menos peculiar, pues consigue salirse de los cánones impuestos a la samba desde su surgimiento, permitiendo numerosos casos de hibridación poco comunes en el panorama musical brasileño. Esto último resulta especialmente relevante, ya que enraizaría con la inagotable disputa entre las clases bajas y altas por la custodia de los géneros musicales originados en Brasil. En lo que respecta a sus inicios, nos hallamos ante un género que procede de núcleos acomodados y en donde surgen artistas de la talla de João Gilberto quien, junto a Elizeth Cardoso lanza el famoso "Chega de saudade" (1958), éxito, que junto a "Desafinado" y "Samba de uma nota só" de Newton Mendoça y Tom Jobim, configuran los paradigmas del nuevo estilo musical. Junto a estos, habría que destacar la presencia de Nara Leão y del poeta y letrista Vinícius de Moraes, ambos nutridos de la bohemia carioca. Acostumbrados a ritmos jazzísticos y a géneros como el be bop, dicho conjunto hizo de su educación musical y sentimental un estilo. Según el historiador Tinhorão: "a finalidade desses conjuntos era tocar para um público interessado apenas em dançar na penumbra (...) os cantores... passaram a imitar também os cantores americanos, adotando-Ihes as vocalizações destinadas a integrar a voz no conjunto orquestral" (1999, p. 311), factor que dificultaría su difusión teniendo en cuenta que las clases medias-bajas aún seguían dentro del clima estadonovista y en consecuencia veían estas producciones como inventos subversivos.

La imagen que intenta evocar Tinhorão cuando habla de un "dançar na penumbra" nos indica que estamos ante un estilo rupturista, con ritmos muchos más lentos y más intimistas, los cuales establecen una relación de cercanía con el auditorio. Según Augusto de Campos, de esta cálida atmósfera resultante surge un nuevo lenguaje y, por ende, una nueva forma de cantar (y contar): "el aspecto que desde el inicio llamó la atención al oyente fue el carácter coloquial de la narrativa musical” (2006, p. 79). Con el surgimiento de la bossa nova, la música, pasa a concebirse en términos casi narratológicos que, pudiendo usar otro formato, escoge la variante coloquial para hacer llegar su mensaje de una manera mucho más directa y emotiva. Dicho mecanismo de expresión no es casual, pues como bien señala Campos, en las letras de Vinícius de Moraes ya se observaba "una impostación poética que se aproximaba más a las baladas medievales que al lenguaje simple y espontáneo que caracterizó a las letras de la bossa nova y sus propias contribuciones para el estilo" (2006, p. 84).

Otro apunte que no podemos pasar por alto es la relación de causalidad subyacente a la atmósfera creada por los compositores de bossa nova y el, en palabras de Robert Hodge, lenguaje familiarizante ${ }^{2}$, una especie de código que se revela en clave metalingüística y que, de manera casi innata, es conocida y compartida por ambos integrantes. La invención de Hodge entronca así con uno de los argumentos que manifiesta Augusto de Campos en su libro Balance(o) de la bossa nova y otras bossas:

Las manifestaciones musicales de cámara exigen del compositor no sólo un tratamiento musical más depurado y detallista, sino también un cuidado mayor en la selección de textos, ya que su contenido, dada la estrecha relación intérprete-público, se pone en evidencia mucho más. Por esa razón la importancia del texto en la bossa nova (...) sería incompleto un estudio de este nuevo estilo musical si no nos centráramos más demoradamente en su análisis (Campos, 2006, p. 87).

Teniendo en cuenta estas consideraciones, y habiendo trazado el camino que toma la samba para convertirse en objeto de análisis, sería conveniente señalar una cita que, creemos, enraíza con la concepción de la música como acto comunicativo: "La canción como discurso se debe entender como una forma multisemiótica en la 
- el RECURSO METALINGÜístico Y LA PERFORMATIVIDAD EN LA SAMBa.

UNA PROPUESTA DE ANÁLISIS DESDE LA SEMIÓTICA CULTURAL •

SANDRA FUENTES DE AZEVEDO

que la letra, música y la interpretación tiene su propio significado potencial, con la posibilidad de transmitir contenidos ideológicos" (Hodge, 1999, p. 161), o dicho de otra forma por el mismo Hodge "Las relaciones implicadas en la producción y la recepción de una canción normalmente representan las relaciones que se producen dentro de la sociedad misma" (p. 157). En definitiva, el autor-compositor tiene en sus manos la oportunidad de ser un reflejo de la sociedad, pero la música en sí tiene la capacidad de representar los universos semióticos que la conforman.

\section{Metassamba y samba metapoético}

Teniendo en cuenta los aspectos mencionados en el apartado anterior damos paso al Texto, "objeto" resultante de la actividad semiótica. De la voluntad del compositor por reivindicar su arte y la consiguiente reformulación vislumbramos un código de índole metalingüística presente en la mayor parte de sambas. Comúnmente el fenómeno metalingüístico se ha asociado con el lenguaje natural y literario, algo que por el contrario no se da en el discurso musical. En el apartado anterior señalábamos la estrecha relación que mantiene la música y la poesía ya no solo en la bossa nova, sino en la música popular brasileña en general. De ahí que lo más conveniente (dado que no gozamos de los recursos suficientes para abordar el plano musical) sea hacer un análisis del código literario presente en la samba.

El tratamiento frente a ambos tipos de creación artística es prácticamente el mismo. Tanto en uno como en otro intervienen: un autor, que reflexiona acerca de la importancia del código que utiliza y el mensaje que quiere hacer llegar; el texto el cual se presenta como objeto artístico autosuficiente; y el receptor, a quien le corresponde la labor activa de interpretar y contribuir con la circulación de dicho texto. En última instancia, habría de añadirse la palabra, la cual cobra un gran protagonismo a través del metalenguaje, pasando de ser un mero objeto a ser una herramienta presta para ser decodificada y en torno a la que gira toda la actividad significante.

En lo que respecta al estudio del discurso metalingüístico aplicado a la samba destacamos la labor de André Nemi Conforte quien en su tesis As metalinguagens do samba (2007, p. 15) identifica tres tipos de sambas metalingüísticas: a) Metassamba: "O samba que se volta para o próprio gênero, ou seja, para sua história, para suas agruras ou seus sucessos"; b) sambas metapoéticos: "O samba visto como composição poética, voltado para o próprio ato de fazer poético, para os mistérios que regem o processo da inspiração"; c) sambas metalinguísticos propriamente ditos: "Sambas nos quais o compositor faz questionamentos acerca do idioma... aqui se trata do código língua portuguesa sendo utilizado... para falar da língua portuguesa".

Todos estos tipos nos interesan porque poseen un denominador común: la capacidad de autorreferenciarse. Entre las múltiples definiciones que ofrece Conforte para explicar la samba metapoética, recalcamos el siguiente argumento: "Pensamos constituir o universo do samba (...) como elemento de nossa cultura, um sistema semiótico próprio, daí defendermos a existência do chamado Metassamba" (2007, p. 51). Esto vendría a significar que el metalenguaje es un rasgo inherente a la samba y que, por tanto, pertenece a ella tanto o más que otros rasgos. Así, la samba es quien produce metalenguaje y no viceversa. El discurso hace que percibamos que él es el propio responsable de la construcción de identidad, siendo este quien se tome a sí mismo como objeto, sirviéndose de la ilusión de distancia (como si se tratase de otro) tal y como pretendía ilustrar Guillermo Carnero al hablar de un "doble nivel discursivo"3.

Sin embargo, en el caso que nos compete, solamente incidiremos en los dos primeros tipos, la metassamba y la samba metapoética, ya que nuestro propósito principal reside en acercarla lo más posible al universo literario, e incidir en el tercero conllevaría un estudio más exhaustivo sobre la naturaleza lingüística del portugués. Acerca del primer tipo, la metassamba, Conforte matiza:

Caracteriza-se pela reflexão e pela referência ao gênero samba e aos diversos elementos que laboram na construção de seu universo: o sambista, o morro, os instrumentos musicais, as escolas de samba, a indústria do carnaval, etc. É dentre os chamados sambas metalinguísticos, certamente, o de maior ocorrência (...). O objetivo do compositor é traçar um painel histórico do gênero (2007, p. 55). 
- EL RECURSO METALINGÜÍSTICO Y LA PERFORMATIVIDAD EN LA SAMBA.

UNA PROPUESTA DE ANÁLISIS DESDE LA SEMIÓTICA CULTURAL •

SANDRA FUENTES DE AZEVEDO

Como prueba de ello la música popular brasileña alberga canciones del tipo "Samba não é brinquedo" (1956) en la cual Noel Rosa despliega una serie de redes isotópicas reconocibles por la comunidad. En ella no solo se hace alusión a diferentes signos típicos de la cultura brasileña, sino que además el compositor aprovecha la presencia de estos para hacer una llamada a la tradición, algo que posibilitará lo que Mijail Bajtin llama "dialogismo"4 (más tarde reformulado por Julia Kristeva bajo el nombre de "intertexto"5) y que en la samba es esencial para garantizar la perdurabilidad y conservación del género.

En lo que respecta al segundo tipo, la samba metapoética, el investigador brasileño establece una relación entre ésta y el fenómeno metapoético, algo que, como podemos comprobar, termina por corroborar la relación de la samba con el universo literario y que a su vez demuestra la licitud de un análisis como que el que pretendemos aplicar:

Em sua finalidade a construção do samba metapoético em nada diferirá da chamada Metapoesia. Consiste no momento em que o compositor se entrega à reflexão sobre o seu próprio processo de elaboração, muitas vezes atribuindo à inspiração uma natureza mística (2007, p. 68).

Este fenómeno estará presente en canciones como "A maldição do samba" (2003) del rapero Marcelo D2 o "Samba de benção" (1967), de Vinicius de Morães y Baden Powell. En ellas los autores no solo se sumen en un diálogo con su propio elemento de trabajo (a la manera diríamos, del escultor), sino que además entran en conversación con personajes del pasado los cuales son expuestos a un público con el que se procura legitimar una cierta relación de camaradería.

\section{4. ¿Cómo hacer cosas con samba?6: cuatro principios básicos}

Teniendo en cuenta lo dicho hasta el momento habríamos de recordar algunos aspectos: en primer lugar, la música es un mecanismo de comunicación en el que interfieren una serie de factores los cuales hacen posible su funcionamiento; en segundo lugar, gracias a esta cualidad comunicativa, la música (concretamente la samba) puede ser estudiada desde un punto de vista lingüístico, pues presenta claros signos de metalenguaje y, por tanto, de autorreferencialidad. En última instancia, quedaría por resolver la cuestión de lo poético en la samba, que si bien ha sido mencionada por su semejanza con la metapoesía (establecida por Jakobson en sus funciones del lenguaje), no se ha incidido aún en su particularidad para crear universos ficcionales, tal y como ocurre en el ámbito literario.

Antes de adentrarnos en el apartado, deberíamos plantearnos algunas cuestiones, como, por ejemplo, a qué se debe esa inclinación que presenta la samba para crear universos. Dicho de otro modo ¿qué intencionalidad se esconde tras la elección del formato metalingüístico para hacer llegar un mensaje $n$ ? Bajo esta pregunta subyace el segundo apartado, ya mencionado en los estudios de González Martínez, quien recordamos, establecía dos criterios: el de elección (el cual ya tratamos en el primer apartado) y el de intención, que vendría a situarse en el nivel de análisis en el que nos encontramos. Llegados a este punto deberíamos preguntarnos también cómo toma consistencia este código metalingüístico que, al parecer, es el que posibilita la existencia y la proliferación de dichos mundos. Para solventar estos interrogantes González Martínez alude a los Ilamados, "procesos de modalización", muy ligados al concepto de "acto performativo", que John Austin desarrolla en su obra Cómo hacer cosas con palabras (1962) y que más tarde rescata Judith Butler en El género en disputa (1990). Esta última nos sirve en tanto que usa el método performativo para explicar algunas de las bases de la teoría queer, demostrando así la flexibilidad que dichos preceptos pueden llegar a tener en el momento en el que son aplicados a ámbitos que hasta el momento no se creía posible.

Así pues, retomamos las pautas teóricas del investigador González Martínez, quien en su ensayo "El estudio de la obra musical desde la semiótica literaria" (1994) expone una de las claves que nos permiten vincular los estudios sobre metalenguaje con los actos performativos: 
- EL RECURSO METALINGÜÍSTICO Y LA PERFORMATIVIDAD EN LA SAMBA.

UNA PROPUESTA DE ANÁLISIS DESDE LA SEMIÓTICA CULTURAL

SANDRA FUENTES DE AZEVEDO

La música implica un deseo de hacer cosas con los sonidos, un proyecto cuyos intereses afectan al individuo y a la colectividad a la que pertenece: establecer una comunicación, crear una realidad artística, exponer una determinada idea, expresar sentimientos y estados de ánimo, participar en un acontecimiento social, mostrar determinadas habilidades, estimular reacciones en los demás, etc. (González Martínez, 1994, p. 786).

El fenómeno mediante el cual la música es capaz de crear realidades se produce gracias a lo que el investigador denomina "procesos de modalización", que en esencia vienen a ser semejantes a los "enunciados realizativos" que analiza Austin. Sin estos, sencillamente no existiría el universo simbólico. Uno de los factores de mayor relevancia en el proceso interpretativo generado por el compositor, quien según González Martínez es un "manipulador no violento" (1996, p. 543), es el de la presuposición, la cual "se nos revela como un elemento esencial en el desarrollo discursivo (narrativo y sintagmático) de la obra musical, y es en este sentido en el que Eco lo define como una modalidad determinada de cooperación interpretativa" (Eco, 1979; apud, González Martínez, 1996, p. 543). A este acto de presuponer se une la cualidad fáctica del propio acto de manipular, por la cual un enunciado se hace posible, es decir, se materializa; "Esta concepción de la manipulación -específica el investigador- incluye la persuasión en general, y sus diversas concreciones particulares (persuadir, convencer, manipular...) en tanto que transformación de un poder - ser o poder - hacer del sujeto manipulado en un deberser o deber-hacer" (Eco, 1979; apud, González Martínez, 1996, p. 543). En consecuencia, el ser del enunciado pasa a constituirse como un hacer a través de dichos procesos de modalización: "La interpretación musical como actividad incluye el acto de decir algo, el que tiene lugar al decir algo y que acontece por decir algo" (González Martínez, 1996, p. 545), argumento que está en relación directa con los actos realizativos de Austin.

Gracias a esta idea podemos concebir la música como un mecanismo que además de comunicar, genera acciones que consiguen traspasar el velo ficcional, de ahí que las teorías del lingüista se ajusten tan bien al lenguaje de la samba, pues en ella reside lo cotidiano y lo poético a partes iguales. No obstante, no debemos olvidar que uno de los cometidos principales de la samba es el de aleccionar a sus oyentes, por lo que el discurso ordinario también tendrá un papel protagonista aquí.

Tras este trasvase ficción-realidad tiene lugar un salto por el cual se elaboran lo que Lubomíz Doležel denomina, "mundos posibles". Según éste, el mundo ficcional se instituye como posible a través de un proceso de autentificación que no es otro que la misma fuerza ilocucionaria que referencia Austin. Este suceso se da sobre todo por la cualidad poiética del texto, en donde "gracias a la fuerza ilocutiva especial (...) los posibles se hacen existentes ficcionales, siendo así, que los mundos posibles se conviertan en objetos semióticos" (Doležel, 1999, p. 47), a lo que añade:

La poesis textual, al igual que toda actividad humana tiene lugar en el mundo real, sin embargo, construye (es capaz de) reinos ficcionales cuyas propiedades, estructuras y modos de existencia son, en principio, independientes de las propiedades, estructuras y modos de existencia de la realidad (Doležel, 1999, p. 47).

Ante esta disyuntiva los valores de verdad quedan relegados, dotando de mayor relevancia al rasgo de verosimilitud (entendida a la manera aristotélica) en tanto que universo válido para los receptores que lo usan en su propio beneficio: "La semántica de los mundos posibles insiste en que es el autor quien construye el mundo y en que el papel del lector es reconstruirlo" (Doležel, 1999, p. 44). Por tanto, el que un enunciado sea verdadero o falso no importa si consigue cumplir su cometido principal: servir de modelo para el pueblo brasileño. Dicho salto ficción-realidad consigue reafirmarse gracias a la capacidad innata de los mundos posibles para autentificarse por medio de "la función intensional"7 algo que, según Doležel, "acarrea consecuencias radicales para la semántica de la ficción” (Doležel, 1999, p. 213).

Teniendo en cuenta esto, proponemos cuatro principios básicos que, desde nuestro punto de vista, emergen de los criterios de modalización y que demuestran el grueso conceptual de gran parte de las sambas metalingüísticas. Así, identificamos: el "principio de privilegio", solo los privilegiados pueden bailar samba, entre ellos la gente de morro, los desafinados, los marginados, es decir, grupos basados en imágenes 
- el RECURSO METALINGÜÍSTICO Y LA PERFORMATIVIDAD EN LA SAMBa.

UNA PROPUESTA DE ANÁLISIS DESDE LA SEMIÓTICA CULTURAL

SANDRA FUENTES DE AZEVEDO

estereotipadas asociadas al carácter del brasileño; "principio de inmortalidad": la samba está, no nace ni muere, se regenera, es inspiración pura y, por tanto, es inmortal; el "principio de contradicción": la samba es alegre y es triste. Es un estado de ánimo en permanente contradicción a imitación de la vida. De igual manera es sentimiento, pero también corporeidad; y por último, el "principio de saudosismo", la samba se basa en el sentimiento inefable de saudade, y la saudade es en sí samba.

\subsection{Principio de privilegio y principio de inmortalidad}

Entre las muchas composiciones que reflejan estos principios de manera simultánea encontramos " $A$ maldição do samba" (2003) del rapero Marcelo D2. En ella se tratan temas relacionados con el universo de la samba desde el punto de vista de la cultura del rap o del hip-hop. Ponemos este ejemplo, y no otro, para demostrar la longevidad que presentan ambos principios que si bien se encuentran en la contemporaneidad aparecen del mismo modo en muchos de los clásicos de la música popular brasileña.

Quer dançar? Quer dançar? Então prepara

A maldição bateu, sambou, nunca mais pára

E tá na cara, a raiz tá cravada no chão

Do tronco ao fruto com a canabinol fazendo a conexão

E sangue bom, eu disse, sangue bom

Tem coisas que invadem o coração já disse o João, não

Ninguém faz samba porque prefere

Sobre o poder da criação força nenhuma no mundo interfere

(...). É coisa fina, dj com tamborim.

Fortaleceu meus braços, abriu minha cabeça

Um ser humano digno, aconteça o que aconteça,

(...) Globalizado ou não eu mantenho os meus laços

Do hip hop ao samba é compasso por compasso

Nem feliz, nem aflito, nem no lugar mais bonito

Nada mais interfere no quadro que eu pinto

A bênção velha guarda o samba de terreiro

A maldição te pega no Rio de Janeiro.

A primera vista podemos observar elementos dialógicos: “Quer dançar? Quer dançar?” algo que de manera consustancial conllevaría la inclusión del oyente mediante el tono didáctico. La canción en sí está abarrotada de signos culturales y referencias que bien podrían encajar en el grupo de "samba propiamente dito" y que pone el punto de mira en el propio lenguaje de la calle. De todos modos, lo que aquí nos ocupa es el principio de inmortalidad de la samba, cuya esencia ha permanecido inalterable a pesar de los años. De ahí que el cantante diga: "É coisa fina dj con tamborín", entremezclando lo moderno con lo antiguo. O más claro aún: "E tá na cara, a raiz tá cravada no chão/ Do tronco ao fruto com a canabinol fazendo a conexão". Con esto Marcelo D2 se propone la labor titánica de condensar el tiempo, buscando con ello conciliar las raíces ("cravadas no chão") con costumbres propias de la actualidad, como el consumo de cannabis, símbolo característico de la estética del rap. Por eso mismo se habla de una conexión, pues será en ésta en donde se demuestre tanto la capacidad de la samba para permanecer firme, como su determinación para convertirse en una entidad cultural imperecedera.

Por otro lado, llaman la atención aquellos aspectos que sugieren la problemática de la sangre (cuestión generacional), pues suponen un claro ejemplo del principio de privilegio. Tal y como establece Seu Jorge en "O samba tai" (2002): "O samba tá no sangue daquele que sabe sambar" a lo que Marcelo D2 parece corroborar diciendo "é sangue bom, eu disse sangue bom". Así, tanto uno como otro revelan el rasgo hereditario y la pureza de la samba, la cual no habría sido posible si sus oyentes no hubiesen sido fieles a las leyes que el mismo género ha ido imponiendo. Versos después se dice: "Tem coisas que invadem o coração já disse o João, não". Volvemos a encontrarnos con otro pasaje intertextual, en donde se cita directa e indirectamente a João Gilberto, quien en "Desafinado" (1959) expresaba "no peito dos desafinados também bate um coração". Con este fenómeno 
- EL RECURSO METALINGÜÍSTICO Y LA PERFORMATIVIDAD EN LA SAMBA.

UNA PROPUESTA DE ANÁLISIS DESDE LA SEMIÓTICA CULTURAL •

SANDRA FUENTES DE AZEVEDO

intertextual aparte de perpetuarse el nombre de grandes compositores brasileños, lo que se busca es establecer una suerte de diálogo con aquellos a quienes se ha considerado siempre como maestros y deudores. En cuanto a "ninguém faz samba porque prefere", vendría a entrar en la dinámica "el genio no se hace, nace", es decir, quien hace samba lo hace porque está destinado a hacerlo, porque alguien (Dios, lo más probable) le ha otorgado ese "poder da criação". La temática en torno a los privilegios de ser "sucesor de la samba" continua a lo largo de toda la composición: "Fortaleceu meus braços, abriu minha cabeça/ Um ser humano digno", en donde, además de reflejar las capacidades fortificantes de la samba, se hace referencia a aquello que ya expresaba Candeia en "Luz da inspiração" (1977), una de las canciones que mejor reflejaría el misticismo inherente al acto de crear. En ese caso, podríamos calificar como análogos los versos de Candeia: "Sinto-me em delírio/ Acordes musicais/ Invadiram o meu ser, sem querer", destacando el "sin querer" significativamente próximo al "ninguém faz samba porque prefere" de la canción de Marcelo D2, cuya fórmula se extrae, directa y textualmente, de la icónica pieza "Poder da criação" (1980) de João Nogueira y Paulo Cesar Pinheiro. Ante esta disyuntiva, Candeia posiblemente sentenciaría: "porque se faz sem querer".

En resumen, cuando decimos que la samba es una entidad "inmortal" lo estamos haciendo desde una perspectiva ontológica, es decir, concibiéndola como un objeto que carece de forma pero que, sin embargo, está ahí a pesar de no saber muy bien cómo. Si tomásemos prestadas las palabras de Candeia lo importante sería ser conscientes de que late en las venas, de que vive y muere en nosotros. "Nasceu no pasado, vive no presente", y, por tanto, tiene la capacidad (auto)suficiente como para validarse a sí misma.

\subsection{Principio de contradicción y principio de saudosismo}

Otra de las grandes constantes se concentraría en lo que hemos denominado, principio de contradicción, claro reflejo de la realidad brasileña. Y es que, en sí, la samba, surgió de la confrontación entre dos pares, los africanos y los indígenas, a los que más tarde se unirían un sinfín de culturas procedentes de otros países y que darían como resultado el concepto de brasilidade, tal y como lo entendemos hoy. Para ejemplificar este tipo hemos escogido "Samba da benção" producida por Vinícius de Moraes junto al guitarrista Baden Powell. Uno de los rasgos quizá más interesantes de esta canción es su capacidad totalizante que le permite abarcar numerosos casos de intertextualidad, algo que en gran medida contribuye a crear un interminable tejido polifónico y que aglutina tanto referencias de canciones pasadas como de composiciones futuras.

Mas pra fazer um samba com beleza
É preciso um bocado de tristeza
É preciso um bocado de tristeza
Senão, não se faz um samba não

Senão é como amar uma mulher só linda

E daí? Uma mulher tem que ter

Qualquer coisa além de beleza

Qualquer coisa de triste

Qualquer coisa que chora

Qualquer coisa que sente saudade

Um molejo de amor machucado

Uma beleza que vem da tristeza (...)

Fazer samba não é contar piada

E quem faz samba assim não é de nada

O bom samba é uma forma de oração

Porque o samba é a tristeza que balança

E a tristeza tem sempre uma esperança

A tristeza tem sempre uma esperança

De um dia não ser mais triste não. 
- EL RECURSO METALINGÜÍSTICO Y LA PERFORMATIVIDAD EN LA SAMBA.

UNA PROPUESTA DE ANÁLISIS DESDE LA SEMIÓTICA CULTURAL

SANDRA FUENTES DE AZEVEDO

"Porque o samba nasceu lá na Bahia/ E se hoje ele é branco na poesia/ Se hoje ele é branco na poesia/ Ele é negro demais no coração". Aquí, Vinícius hace uso de la concepción estereotipada que cree que la tradición poética procede de Occidente al referirse "al blanco", mientras que la samba (no olvidemos, sentimiento inefable) está vinculada a un estado de espíritu "ele é negro demais no coração" y como tal supone un motivo orgullo, así como el fruto de una mezcla obtenida tras la esclavitud.

Uno de los sentimientos que bien podríamos vincular a este principio es el de la saudade, pues su existencia se debe a la contradicción en sí misma. Esto último se especifica claramente en el verso: "qualquer coisa que sente saudade/ um molejo de amor machucado/ uma beleza que vem da tristeza". Comprobamos pues, que beleza y tristeza, conceptos naturalmente antagónicos, quedan en un mismo plano argumental. Nuevamente encontramos aspectos comunes con los otros principios, como resulta de los versos "Fazer samba não é contar piada/ E quem faz samba assim não é de nada/ O bom samba é uma forma de oração" muy en la línea de "Samba não é brinquedo" (1956) en la que Tom Jobim, bajo un claro sentimiento de privilegio, intenta institucionalizar la samba a través del alegato místico y la eleva a la categoría de oración.

\section{Conclusión: una enciclopedia para una brasilidade}

En uno de sus ensayos sobre semiótica de la ficcionalidad, González Martínez expresa:

El universo de discurso que instaura la obra es el trasunto de un mundo posible generado en la conciencia de un grupo concreto de individuos, y el universo de sentido textual se incluye como una parte constituyente en el patrimonio cognoscitivo del hombre en cuanto ser social: en el sentido en el que los propios códigos utilizados forman parte de una enciclopedia, entendida esta, de acuerdo con Umberto Eco (González Martínez, 1996, p. 542).

Palabras que nos llevan a considerar aquellos famosos versos de "Ministro do Samba" (1973): "O samba bem merecia ter ministério algum dia" cantaba el gurú Batatinha. Tal y como hemos ido viendo a lo largo de todo el análisis, existe en la samba una enorme carga sígnica. Esto sucede gracias a su rasgo metalingüístico, cuya función regeneradora estimula la creación incesante de fenómenos isotópicos. A consecuencia de esta oscilación en la que la samba no deja de perpetuarse, se construye la llamada Enciclopedia Media, estadio final de nuestro análisis. Tras ésta se esconde toda la actividad semiótica conformada por tejido isotópico e innumerables rutas polifónicas. Según Umberto Eco dicha Enciclopedia surge de un "conjunto de interpretaciones que un grupo social o histórico da a los términos que usa" y que suponen "el único medio con que podemos dar razón, no solo al funcionamiento de cualquier sistema semiótico, sino también de la vida de una cultura como sistema de sistemas semióticos interconectados" (2009, p. 35). Esto explicaría el mecanismo por el cual la samba se ha ido labrando una suerte de biblioteca didáctica a la que recurrir para conocer la memoria histórica. Este fenómeno, semejante al de "semiosis ilimitada"8 no pasa ni mucho menos desapercibido por los creadores de enciclopedias, esos compositores de samba quienes, de forma totalmente genuina, usan sus canciones para poner de manifiesto la urgencia de una plataforma que aúne toda esa riqueza. Buen ejemplo de ello lo encontramos en "Filosofia do Samba" (1971) o en "Máquina de Ritmo" (2008) donde Gilberto Gil declara: "Poderei legar um dicionário/ De compassos pra você". Dichas alusiones surgen pues, de la voluntad que tiene un determinado grupo social de comprender su historia. El acto de reclamar para sí un lugar donde albergar todos los datos recolectados, no hace sino transmitir la conciencia vital que tiene una comunidad. Y es que la Enciclopedia supone "aquello que engloba todo lo que un grupo social sabe sobre el mundo, lo que permite comprender cómo se entiende la gente (...) participar de la enciclopedia misma significa participar en la misma cultura en el sentido antropológico del término" (Eco, 2009, p. 31). Y esto último, es lo que hemos pretendido con el presente estudio. Así pues, a través de la Enciclopedia Media percibimos toda la complejidad del universo de la samba, formada a su vez por dos componentes indisolubles que son esenciales para el proceso de configuración semiótica: el colectivo, formado por compositores y auditorio y la samba en sí, que se erige como objeto artístico autosuficiente. 
- EL RECURSO METALINGÜÍSTICO Y LA PERFORMATIVIDAD EN LA SAMBA.

UNA PROPUESTA DE ANÁLISIS DESDE LA SEMIÓTICA CULTURAL •

SANDRA FUENTES DE AZEVEDO

Finalmente, según las teorías de Eco, uno de los aspectos fundamentales para la construcción de esta Enciclopedia Media es la concepción de un arte que sepa reciclarse, es decir, que tenga una capacidad para desplazar ciertos aspectos de una cultura y reavivar otros en función del contexto. Este hecho dará lugar a una memoria colectiva viva, la cual se apropia y desapropia por inercia de elementos que considera o no útiles: "la cultura no cesa de excavar, en el sentido literal del término para sacar a la luz datos y testimonios sobre culturas pasadas" (Eco, 2009, p. 45). Y es aquí cuando nos vemos en la necesidad de mencionar de nuevo la capacidad metalingüística de la samba, pues sin ella no habría autorreferencia, no habría red isotópica, no habría, en definitiva, proceso incesante de semiosis y configuración del espíritu de la brasilidade. 
- EL RECURSO METALINGÜÍSTICO Y LA PERFORMATIVIDAD EN LA SAMBA.

UNA PROPUESTA DE ANÁLISIS DESDE LA SEMIÓTICA CULTURAL •

SANDRA FUENTES DE AZEVEDO

\section{NOTAS}

1 Término que se usa para denominar a los primeros negros que llegaron a Brasil en tiempos de la Colonización. Procedían en su mayoría de áreas del Congo y de Angola. Según Diniz fueron "responsáveis pela entrada de diversos instrumentos e folguedos no país (...) estão ligados às festas do samba em seus primórdios, ainda com enormes características rurais" (2006, p. 24).

2 "El cantante necesita disponer de un bagaje de fórmulas para poder repetirlas en diferentes contextos y también debe tener muy a mano un conjunto de temas para insertarlos de forma semejante en cualquier relato, y así adaptarlo a los nuevos contextos con el mínimo de cambios" (Parry y Lord, 1976; apud Hodge, 1999, p. 159).

3 "Metapoesía es el discurso poético cuyo asunto, o uno de cuyos asuntos, es el hecho mismo de escribir poesía y la relación entre autor, texto y público. Con otras palabras, un metapoema es un poema que tiene dos niveles discursivos paralelos. En el primero, se trata de lo que habitualmente entendemos por poema. En el segundo, que discurre paralelamente al primero, y entremezclado con él, el poema reflexiona sobre su propia naturaleza, su origen, condicionamientos y demás circunstancias" (Carnero, 1983).

4 "El dialogismo es inherente al lenguaje mismo (...) el diálogo es la única esfera posible de la vida del lenguaje. Hoy día podemos hallar las relaciones dialógicas en varios niveles del lenguaje (...) el diálogo no es solo el lenguaje asumido por el sujeto: es una escritura en la que se lee al otro. Así, el dialogismo bajtiano designa la escritura a la vez como subjetividad y como comunicatividad, o mejor dicho, como intertextualidad: frente a ese dialogismo, la noción de 'persona-sujeto de la escritura' empiezan a desvanecerse para cederle el puesto a otra, la de 'la ambivalencia de la escritura'” (Kristeva, 1997, pp. 5-6).

5 "Todo texto se construye como mosaico de citas, todo texto es absorción y transformación de otro texto. En el lugar de la noción de intersubjetividad se instala la de intertextualidad, y el lenguaje poético se lee, por lo menos, como doble" (Kristeva, 1997, p. 3).

${ }^{6}$ En este apartado nos proponemos trazar un vínculo entre el acto metalingüístico en la samba y la capacidad del lenguaje para crear cosas, tal y como ilustra John Austin en su obra Cómo hacer cosas con palabras, de ahí el título escogido. Asimismo, intentamos demostrar que la samba, cuyo código tiene claros rasgos metalingüísticos, es capaz también de realizar mundos que se inserten en la memoria real y colectiva.
7 "Combinación de elementos el mundo ficcional con expresiones (mecanismos) de la textura (...) Como tal, el concepto proporciona una base común para nuestra teoría de la identidad textual: une el mundo ficcional de un texto con los rasgos característicos de su estilo literario" (Doležel, 1999, p. 101); "Una función que proyecta el mundo ficcional en una textura específica" (p. 107).

8 "La enciclopedia genera siempre nuevas interpretaciones en función de los contextos y las circunstancias. Por lo tanto, de ella nunca se da una representación definitiva y cerrada (...) en este sentido la enciclopedia es potencialmente infinita porque es móvil y los discursos que hacemos tomándolo como base la ponen una y otra vez en duda" (Eco, 2009, pp. 31-32). 


\section{REFERENCIAS BIBLIOGRÁFICAS}

Austin, J. (2018). Cómo hacer cosas con palabras. Barcelona: Paidós Básica.

Butler, J. (1990). Gender trouble. Estados Unidos: Routledge.

Campos, A. (2006). Balance(o) de la bossa nova y otras bossas. Buenos Aires: CABA.

Carnero, G. (1983). La corte de los poetas. Revista de Occidente. In P. Provencio. Poéticas españolas contemporáneas (pp. 44-60). Madrid: Hiperion, 1988.

Conforte, A. N. (2005). Samba, Metalinguagem e metadiscurso (vol. 1, pp. 254-258). VIII Fórum de Estudos Linguisticos - caderno de comunicações. Rio de Janeiro: Botelho.

Conforte, A. N. (2008). O interdiscurso no samba. Cadernos do CNLF (CiFEFil), XI, 126-137.

Diniz, A. (2006). Almanaque do samba. A história do samba, o que ouvir, o que ler, onde curtir. Rio de Janeiro: Jorge Zahar Ed.

Doležel, L. (1999). Estudios de poética y de teoría de la ficción. Murcia: Servicio de Publicaciones de la Universidad de Murcia.

Doležel, L. (1999). Heterocósmica. Ficción y mundos posibles. Madrid: Ed. Arco/Libros.

Eco, U. (1986). La estructura ausente. Introducción a la semiótica. Barcelona: Lumen.

Eco, U. (2009). Cultura y semiótica. Madrid: Ediciones pensamiento, Círculo de Bellas Artes.

Fenerik, J. A. (2005). Nem do morro nem da cidade. As transformações do samba e a indústria cultural (1920 1945). São Paulo: Annablume.

González Martínez, J. M. (1994). El estudio de la obra musical desde la semiótica literaria. In Investigaciones Semióticas V. Semiótica y modernidad (vol. II). La Coruña: Universidad de La Coruña.

González Martínez, J. M. (1996). Los procesos de modalización en el discurso músico-literario. In Investigaciones Semióticas VII. Mitos (vol. II, t. II). Zaragoza, Universidad de Zaragoza.

González Martínez, J. M. (1996). Valores sémicos del discurso musical en una semiótica de la ficcionalidad. In Investigaciones Semióticas VI. Mundos de ficción (vol. II, t. I). Murcia: Universidad de Murcia.

González Martínez, J. M. (1998). La dinámica isotópica como fundamento del discurso artístico músico-literario. Imafronte, $\mathrm{n}^{\circ}$ 12-13, 151-162.
González Martínez, J. M. (1999). Los procesos de codificación múltiple en el discurso artístico musical y literario. Imafronte, $\mathrm{n}^{\circ}$ 14, 71-78.

González Martínez, J. M. (2007). Semántica interlingüística. Los conceptos de significado, designación y sentido en una semiótica de la música. Interculturalidad, insularidad, globalización (2 vols., t. I). La Laguna: Universidad de La Laguna.

González Martínez, J. M. (2015). Fundamentos de la semiótica de la Música, De Re Poética. Murcia: Universidad de Murcia.

Hodge, R. (1999). Canción. In A. Teun Van Dijk (Ed.). Discurso y literatura. Nuevos planteamientos sobre el análisis de los géneros literarios. Madrid: Visor libros.

Kristeva, J. (1997). Bajtin, la palabra, el diálogo y la novela. In D. Navarro (Ed.). Intertextualité. Francia en el origen de un término y el desarrollo de un concepto. La Habana: Casa de las Américas, UNEAC.

Santos de Miranda, D. (2007). A cidade e o samba. Logos 26: comunicação e conflitos urbanos, año $14,1^{\circ}$ sem., 84-97.

Tinhorão Ramos, J. (1999). História social da música popular brasileira. São Paulo: Ed. 34.

Vicente Gómez, F. (1984). El concepto de dialogismo en Bajtin. La otra forma del diálogo renacentista. Anuario de la Sociedad Española de Literatura General y Comparada, V, 47-54. 